\title{
Variability of stomatal conductance in the crown of a maritime pine (Pinus pinaster Ait.)
}

\author{
D. Loustau and F. El Hadj Moussa
}

with the technical assistance of M. Sartore and M. Guedon

Laboratoire de Sylviculture et d'Ecologie, INRA, Station de Recherches Forestières de Pierroton, Domaine-de-I'Hermitage, 33610 Cestas, France

\section{Introduction}

Stomatal response of conifers to environmental variables, such as air water vapor deficit, has been reported by many authors (Whitehead et al., 1984; Sandford and Jarvis, 1986). Variations of stomatal conductance $\left(g_{\mathrm{s}}\right)$ related to needle age and situation in the canopy have also been described (Leverenz et al., 1982; Tan et al., 1977).

In order to estimate a general pattern of stomatal conductance $\left(g_{\mathrm{s}}\right)$ in the crown of a maritime pine, the effects of each of these sources of variability have been assessed.

\section{Materials and Methods}

All measurements were made in the crown of a single standard tree from an $18 \mathrm{yr}$ old stand of maritime pine (mean height $=12 \mathrm{~m}$; mean circumference at B.H. $=61 \mathrm{~cm}$ ). A sample of shoots was stratified with respect to whorl height ( 8 levels), branch orientation ( 9 levels) and needle age ( 3 levels).
For each of the 30 shoots, measurements were made on a pair of needles of a single fascicle of the shoot. Measurements of the whole sample were made on $5 \mathrm{~d}$, from 07:00 to 19:00 (U.T.), between June 2, and August 30, 1988. An automatic steady state porometer (LICOR 1600 ) was used with a chamber of $63 \mathrm{cc}$ internal volume. $g_{\mathrm{s}}$ was expressed in $\mathrm{cm} / \mathrm{s}$, on a total leaf area basis.

During the experiment, hourly means of temperature, relative humidity, wind speed and irradiance were calculated from micrometeorological measurements made $2 \mathrm{~m}$ above the canopy. Hourly means of canopy transpiration were also computed from sap flow measurements (Granier, 1985) on a sample of 10 pines (including the sample tree).

\section{Results}

\section{Seasonal pattern}

In the course of the experiment, a dry period began on July 20 . Fig. 1 shows the diurnal pattern of $g_{\mathrm{S}}$ mean \pm SD before this period (June 2) and $40 \mathrm{~d}$ after it began (August 30). 

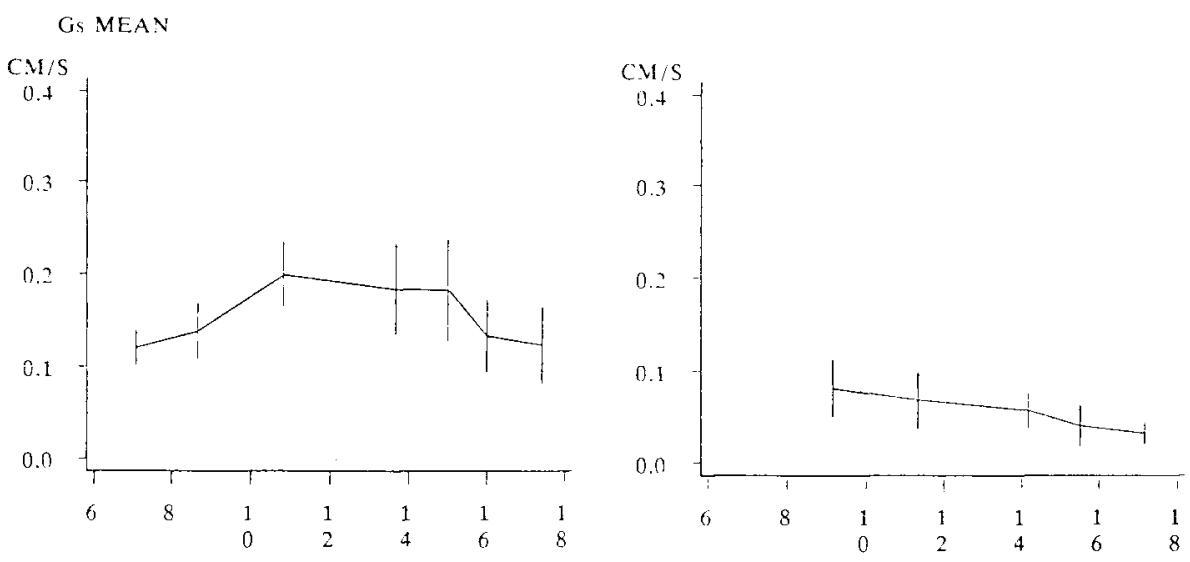

HOUR (U.T.)

Fig. 1. Diurnal pattern of the mean $\pm S D$ (vertical bars) of stomatal conductance $\left(g_{\mathrm{s}} \mathrm{cm} / \mathrm{s}\right.$ ) on June 2, and August 30,1988 .

As had been noticed during previous years, the ratio of canopy transpiration to potential evapotranspiration (PET) (Penman-Monteith) dropped from 0.75 in June to 0.44 in late summer.

Linear regression of $g_{\mathrm{s}}$ on air water vapor deficit $D(\mathrm{~Pa})$ and irradiance $/ r$ $\left(\mathrm{W} \cdot \mathrm{m}^{-2}\right)$ for spring and late summer resulted in the following equation: spring (all data before the beginning of the dry period):

$g_{\mathrm{s}}=0.15-\left(0.95 \times 10^{-4} \times D\right)+\left(1.6 \times 10^{-4}\right.$ $x / r)\left(N=542 ; r^{2}=0.52\right)$.

Late summer (data after the beginning of the dry period):

$g_{\mathrm{s}}=0.08-\left(0.34 \times 10^{-4} \times D\right)+(0.38 \times$ $\left.10^{-4} \times \operatorname{Ir}\right)\left(N=111 ; r^{2}=0.33\right)$.

\section{Variations related to needle features}

\section{Spring}

Because of the diurnal pattern of the variance of $g_{\mathrm{s}}$, all subsequent analyses were conducted on data divided into 3 time periods (before 09:00, 09:00-16:00, and after 16:00 h).
Effects of whorl position, branch orientation, age of needle and interactions were tested using ANOVA. When significant effects were detected, means at each level were compared with Duncan's test.

No significant difference in $g_{\mathrm{s}}$ was found between morning and evening. But between 9:00 and 16:00, significant effects $(<0.05)$ were shown for each of the 3 selected features (Table I).

\section{Late summer}

There was a significant decrease of $g_{\mathrm{s}}$ during the day, but no significant differences in $g_{\mathrm{s}}$ in terms of whorl position, branch orientation or needle age could be detected.

\section{Discussion and Conclusions}

Variations in $g_{\mathrm{s}}$ over a growing season show a seasonal pattern with 2 contrasted periods, before and after the beginning of the dry period. 
Table 1. Mean values of $g_{\mathrm{s}}$ measured between 9:00 and 16:00 for each level of selected features.

\begin{tabular}{llllll}
\hline $\begin{array}{l}\mathrm{g}_{\mathrm{s}} \text { mean } \\
(\mathrm{cm} / \mathrm{s})\end{array}$ & $\begin{array}{l}\text { Whorl } \\
\text { no. }\end{array}$ & $\begin{array}{l}\mathrm{g}_{\mathrm{s}} \text { mean } \\
(\mathrm{cm} / \mathrm{s})\end{array}$ & $\begin{array}{l}\text { Branch } \\
\text { orientation }\end{array}$ & $\begin{array}{l}\mathrm{g}_{\mathrm{s}} \text { mean } \\
(\mathrm{cm} / \mathrm{s})\end{array}$ & $\begin{array}{l}\text { Needle age } \\
(\mathrm{yr})\end{array}$ \\
\hline $0.17 \mathrm{ab}$ & 1 & $0.18 \mathrm{ab}$ & NNE & $0.09 \mathrm{a}$ & 0 \\
$0.18 \mathrm{a}$ & 2 & $0.20 \mathrm{a}$ & ENE & $0.18 \mathrm{~b}$ & 1 \\
$0.18 \mathrm{a}$ & 3 & $0.17 \mathrm{~b}$ & ESE & $0.15 \mathrm{c}$ & 2 \\
$0.13 \mathrm{c}$ & 4 & $(-)$ & SSE & & \\
$0.15 \mathrm{~b}$ & 5 & $0.16 \mathrm{~b}$ & SSW & & \\
$0.17 \mathrm{ab}$ & 6 & $0.17 \mathrm{~b}$ & WSW & & \\
$0.14 \mathrm{bc}$ & 7 & $0.16 \mathrm{~b}$ & WNW & & \\
& & $0.11 \mathrm{c}$ & NNW & & \\
\hline
\end{tabular}

Means with the same letter are not significantly different.

In the pre-drought period, the stomatal response to air water vapor deficit and irradiance explains $52 \%$ of the total $g_{\mathrm{s}}$ variation; $g_{\mathrm{s}}$ decreases as $D$ increases, and increases with $I r$, as observed by many authors (Sandford and Jarvis, 1986; Tan et al., 1977; Running, 1979).

In midday, when $g_{\mathrm{S}}$ variance and mean are high, the general pattern of stomatal conductance of a pine shows significant differences related to needle age, whorl position and branch orientation. Position effects probably reflect a micrometeorological stratification within the crown, and age effects could be related to the physiological development of the needle. Cumulated effects of environmental variables and needle features explained $75 \%$ of the total variation of $g_{\mathrm{s}}$.

During the drought period, the mean and variance of $g_{S}$ were much lower and showed only a slight decrease during the course of the day. Variation in vapor deficit and irradiance explained only $33 \%$ of the variation of $g_{\mathrm{s}}$. No stratification could be shown in the crown at any time of the day.

Soil water deficit is assumed to be the main limiting factor for needle transpira- tion. Stomatal closure could be general throughout the crown and would explain the absence of any stratification.

\section{References}

Granier A. (1985) Une nouvelle méthode pour la mesure du flux de sève brute dans le tronc des arbres. Ann. Sci. For. 42, 81-88

Leverenz J., Deans J.D., Jarvis P.G., Milne R. \& Whitehead D. (1982) Systematic spatial variation of stomatal conductance in a Sitka spruce plantation. J. Appl. Ecol. 19, 835-851

Running S.W. (1979) Environmental and physiological control of water flux through Pinus contorta. Can. J. For. Res. 10, 82-91

Sandford A.P. \& Jarvis P.G. (1986) Stomatal responses to humidity in selected conifers. Tree Physiol. 2, 89-103

Tan C.S., Black A.A. \& Nnyamah J.U. (1977) Characteristics of stomatal diffusion resistance on a Douglas fir forest exposed to soil water deficits. Can. J. For. Res. 7, 595-604

Whitehead D., Jarvis P.G. \& Waring R.H. (1984) Stomatal conductance, transpiration and resistance to water uptake in a Pinus sylvestris spacing experiment. Can J. For. Res. 14, 692700 